Vol 1. No 4. Oktober 2021 P-ISSN : 2774-8022, e-ISSN : 2774-5791

\title{
PENGGUNAAN METODE RESITASI DALAM PEMBELAJARAN MATEMATIKA DI KELAS VIII SMP PEMBANGUNAN UNP PADANG TAHUN PELAJARAN 2005/2006
}

\author{
DERITA HELFI \\ Pascasarjana PMIPA, Universitas Indraprasta PGRI, Jakarta \\ e-mail: andestahelfi@gmai.com
}

\begin{abstract}
ABSTRAK
Belajar adalah proses yang aktif, proses yang diarahkan kepada tujuan dan proses berbuat melalui pengalaman. Jadi, agar siswa benar-benar tertarik dan merespon setiap pembelajaran matematika mereka harus diberi pengalaman-pengalaman berupa tugas-tugas atau latihan yang bersifat merangsang keingintahuannya terhadap materi matematika. Sejauh ini pembelajaran dengan memberikan tugas-tugas atau latihan telah dilakukan oleh guru matematika di SMP Pembangunan UNP Padang, tapi belum terlaksana dengan baik. Guru belum efektif dalam memberikan tugas, guru tidak selalu memeriksa dan memberikan nilai. Akibatnya hanya sebagian siswa yang benar-benar mengerjakan tugasnya dengan baik sehingga tujuan dari pemberian tugas tidak tercapai, yaitu untuk meningkatkan hasil belajar matematika serta meningkatkan keaktifan siswa dalam belajar. Salah satu langkah yang dapat ditempuh oleh guru adalah dengan menggunakan metode resitasi dalam pembelajaran. Tujuan penelitian ini yaitu untuk mengetahui dampak penggunaan métode resitasi terhadap hasil belajar matematika siswa di kelas VIII SMP Pembangunan UNP Padang tahun pelajaran 2005/2006. Hipotesis yang dikemukakan adalah hasil belajar matematika siswa yang diberi metode resitasi lebih baik daripada hasil belajar matematika siswa tanpa menggunakan metode resitasi. Jenis penelitian ini adalah eksperimen dengan model rancangan Randomized Control Group Only Design (RCGOD). Populasi dalam penelitian ini adalah siswa kelas VIII SMP Pembangunan UNP Padang Tahun Pelajaran 2005/2006. Sampel dalam penelitian ini adalah kelas VIII-D sebagai kelas eksperimen dan kelas VIII-A sebagai kelas kontrol. Rata-rata tes akhir siswa kelas eksperimen adalah 61,76 sedangkan rata rata hasil tes akhir siswa kelas kontrol adalah 53,66. Pengolahan data hasil tes akhir dilakukan melalui uji hipotesis yang menggunakan uji-t. Setelah dianalisis diperoleh $\mathrm{t}_{\text {hitung }}=2,33$, sedangkan pada $\alpha=0,05$ dan $\mathrm{dk}-77$, diperoleh harga $\mathrm{t}_{\text {tabel }}=$ 1.67. Karena $t_{\text {hitung }}>t_{\text {tabel }}$ maka hipotesis diterima sehingga dapat disimpulkan bahwa hasil belajar matematika yang diberi metode resitasi lebih baik daripada hasil belajar matematika siswa tanpa menggunakan metode resitasi.
\end{abstract}

Kata Kunci: Pembelajaran Matematika, Metode Resitasi, Randomized Control Group Only Design (RCGOD)

\section{PENDAHULUAN}

Matematika merupakan salah satu alat bantu untuk menjelaskan fenomena-fenomena yang terjadi di alam, maupun kehidupan di masyarakat . Selain itu matematika merupakan salah satu komponen dari serangkaian mata pelajaran yang mempunyai peranan penting dalam bidang ilmu pengetahuan dan teknologi, sebagaimana yang dikemukakan Sundayana (2016) matematika merupakan salah satu bidang studi yang mendukung perkembangan ilmu pengetahuan dan teknologi Jadi penguasaan matematika yang baik juga merupakan dasar yang kuat untuk mempelajari bidang-bidang studi yang lain. Hal tersebut dapat terwujud jika proses pembelajaran matematika dioptimalkan di sekolah-sekolah.

Menyadari eksistensi dan peran matematika yang semakin luas dan esensial sepatutnya setiap pelaku pembelajaran berusaha meningkatkan kualitas pembelajaran matematika. Akan tetapi kenyataannya berdasarkan pengamatan penulis dalam praktek lapangan kependidikan di SMP Pembangunan UN Padang, rata-rata hasil belajar matematika siswa masih rendah. Berdasarkan observasi yang dilakukan di SMP Pembangunan UNP Padang ditemukan bahwa faktor yang menyebabkan hasil belajar matematika siswa rendah adalah siswa tidak serius 
mendengarkan penjelasan guru, tidak mau bertanya, dan tidak termotivasi dalam mengerjakan tugas atau latihan.

Menurut Whittaker (dalam Syaiful, 2008:12), belajar dirumuskan sebagai proses dimana tingkah laku ditimbulkan atau diubah melalui latihan atau pengalaman. Jadi, agar siswa benar-benar tertarik dan merespon setiap pembelajaran matematika mereka harus diberi pengalaman-pengalaman berupa tugas-tugas atau latihan yang bersifat merangsang keingintahuannya terhadap materi matematika. Untuk mengatasi hal tersebut guru diharapkan mampu menerapkan suatu metode pembelajaran yang dapat meningkatkan motivasi siswa dalam menyelesaikan tugas yang diberikan serta aktif dalam belajar. Hal ini sesuai dengan pendapat Asmani (2010:211) yang menyatakan bahwa guru yang baik adalah guru yang sedikit bicara banyak diamnya. Maksud dari pernyataan tersebut adalah guru hanya sebagai fasilitator saja sedangkan peserta didik yang harus aktif melakukan berbagai aktivitas dalam proses pembelajaran dengan melakukan diskusi, kerja kelompok, debat, bertanya dan lempar gagasan. Kegiatan atau aktivitas peserta didik yang dilakukan dalam proses pembelajaran yang demikian akan mewujudkan pembelajaran aktif. Salah satu métode pembelajaran yang dapat meningkatkan motivasi siswa untuk menyelesaikan tugas-tugas yang diberikan serta aktif dalam belajar adalah metode resitasi. Bertitik tolak dari uraian di atas maka penulis tertarik untuk menyelidiki dampak penggunaan metode resitasi dalam meningkatkan hasil belajar matematika siswa.

\section{METODE PENELITIAN}

Penelitian ini tergolong jenis penelitian eksperimen, dimana sampel dikelompokkan menjadi dua kelas yaitu kelas ekpsperimen dan kelas kontrol. Instrumen atau alat pengambil data pada penelitian ini adalah lembar resitasi, tugas latihan dan lembar observasi

Prosedur penelitian ada tiga tahap, yaitu tahap pertama adalah tahap persiapan (menetapkan jadwal penelitian, membuat rancangan pembelajaran, membentuk kelompok belajar), tahap kedua adalah pelaksanaan (kelas eksperimen diberi pengajaran dengan menggunakan metode resitasi dan kelas kontrol tanpa menggunakan métode resitasi). Langkahlangkah pembelajaran menggunakan métode resitasi pada kelas eksperimen melalui beberapa fase, sebagai berikut:

1. Fase pemberian tugas.

- Menjelaska teknis pembelajaran kepada siswa (metode resitasi)

- Menjelaskan tujuan pembelajaran

- MenjelaskanjJenis tugas yang jelas kepada siswa sehingga mereka mengerti apa yang ditugaskan tersebut.

- Memberika tugas sesuai dengan kemampuan siswa.

- Ada petunjuk/sumber yang dapat membantu pekerjaan siswa

- Sediakan waktu yang cukup untuk mengerjakan tugas tersebut.

2. Langkah pelaksanaan tugas.

- Diberikan bimbingan/pengawasan oleh guru. .

- Diberikan dorongan sehingga anak mau bekerja.

- Diusahakan dikerjakan oleh siswa sendiri, tidak menyuruh orang lain.

- Dianjurkan agar siswa mencatat hasil-hasil yang ia peroleh dengan baik dan sistematik.

3. Fase mempertanggungjawabkan tugas.

Hal yang harus dikerjakan pada fase ini adalah:

Laporan siswa baik lisan/tertulis dari apa yang telah dikerjakan.Ada tanya jawab dan diskusi kelas.

Tahap ketiga adalah tahap akhir dimana kedua kelas diberikan tes akhir dengan soal yang -langkah sebagai berikut: membuat kisi-kisi tes, menyusun soal sesuai dengan kisi-kisi tes, memvalidasi soal, uji coba soal, analisis soal tes berdasarkan indeks kesukaran, daya beda, reliabilitas dan klasifikasi soal. 
Data yang diperoleh dari tes akhir diuji secara statistik yaitu menggunakan uji-t, sesuai dengan hipótesis yang dirumuskan(apakah hasil belajar matematika menggunakan método resitasi lebih baik daripada hasil belajar matematika siswa yang belajar tanpa meggunaka método resitasi) sebelum dilakukan uji-t dilakukan uji normalitas dan homogenitas. Berdasarkan hipotesis yang dikemukakan maka dilakukan uji satu pihak dengan hipotesis statistik, yaitu: $\mathrm{H}_{0}: \mu_{1}=\mu_{2}$ dan $\mathrm{H}_{1}: \mu_{1}>\mu 2$ merupakan rata-rata hasil belajar matematika siswa yang belajar menggunakan metode resitasi dan $\mu 2$ merupakan rata-rata hasil belajar matematika siswa yang belajar tanpa menggunakan metode resitasi

\section{HASIL DAN PEMBAHASAN}

Hasil

Setelah dilaksanakan tes akhir pada kedua kelas sampel diperoleh data tentang hasil belajar matematika siswa yang menggunakan pembelajaran dengan metode resitasi dan pembelajaran tanpa menggunakan metode resitasi. Tes hasil belajar di kelas eksperimen diikuti oleh 38 orang siswa dan kelas kontrol oleh 41 orang siswa. Data tersebut kemudian dianalisis sehingga diperoleh deskripisi statistik nilai dari kelas sampel, seperti terlihat pada Tabel berikut:

Tabel 1. Hasil Perhitungan Statistik Data Tes Akhir

\begin{tabular}{c} 
Kelas N $\bar{x}$ s s$^{2} \mathrm{X}_{\max } \mathrm{X}_{\min }$ \\
\hline $\begin{array}{c}\text { Eksperimen } 3861,7614,5210,2410038 \\
\text { Kontrol 41 53,66 16,29 265,33 } 8520\end{array}$
\end{tabular}

Berdasarkan tabel di atas dapat diketahui bahwa nilai rata-rata hasil belajar matematika siswa di kelas eksperimen lebih tinggi dari nilai rata-rata hasil belajar matematika siswa dikelas kontrol. Selain itu keberagaman kemampuan siswa di kelas eksperimen lebih kecil dari kelas kontrol.

Untuk menarik kesimpulan tentang data yang diperoleh dari tes hasil belajar, dilakukan analisis secara statistik. Sebelum melakukan uji hipotesis terlebih dahulu dilakukan uji normalitas dan uji homogenitas dengan menggunakan software MINITAB, dengan hasil sebagai berikut:

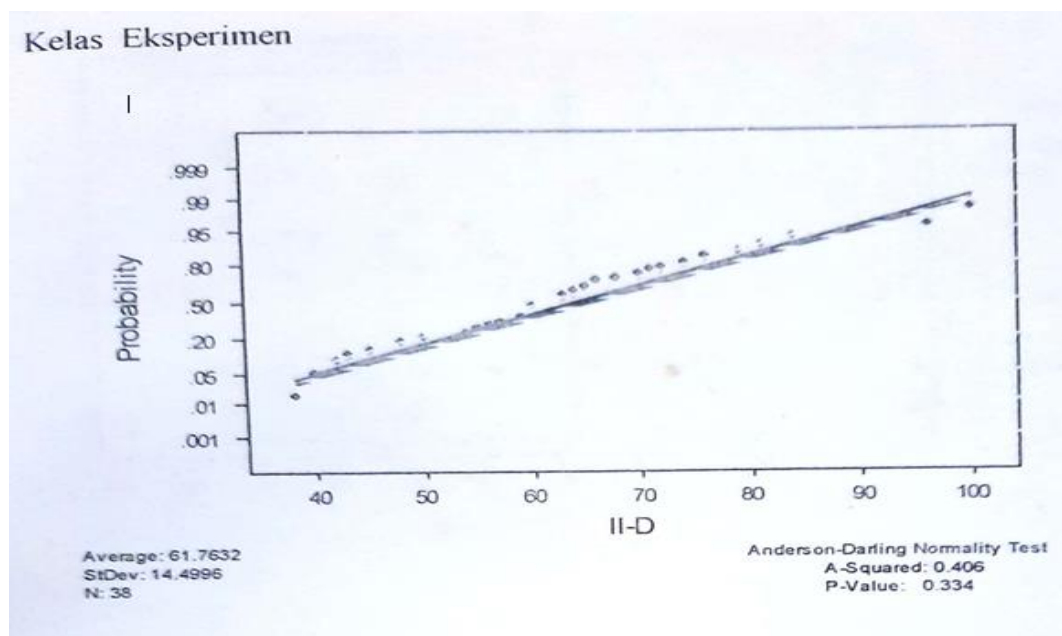

Gambar 1. Uji Normalitas Kelas Sampel 
Kelas Kontrol

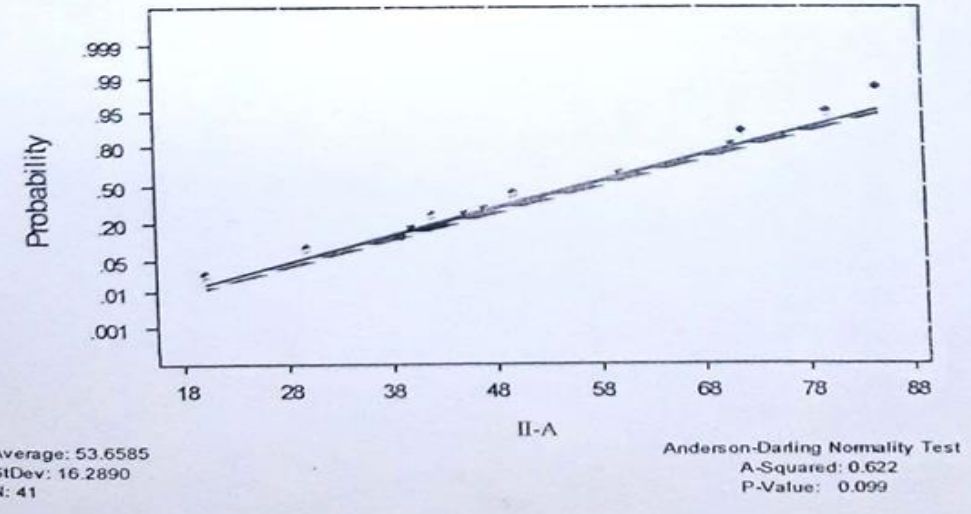

Gambar 2. Uji Normalitas Kelas Kontrol

Dari hasil uji normalitas diperoleh hasil yang menunjukan bahwa pancaran titik-titik pada grafik untuk kelas eksperimen (VIII-D) maupun kelas kontrol VIII-A) berada dekat dengan garis lurus, kemudian P-value kedua kelas sampel juga lebih besar daripada taraf nyata yaitu 0.05, P-value untuk kelas VIII-D adalah 0.334 dan P-value untuk kelas VIII A adalah 0,009. Sehingga dapat disimpulkan bahwa nilai hasil belajar matematika siswa kelas sampel berdistribusi normal. Kemudian hasil uji homogenitas kelas sampel terlihat pada gambar berikut:

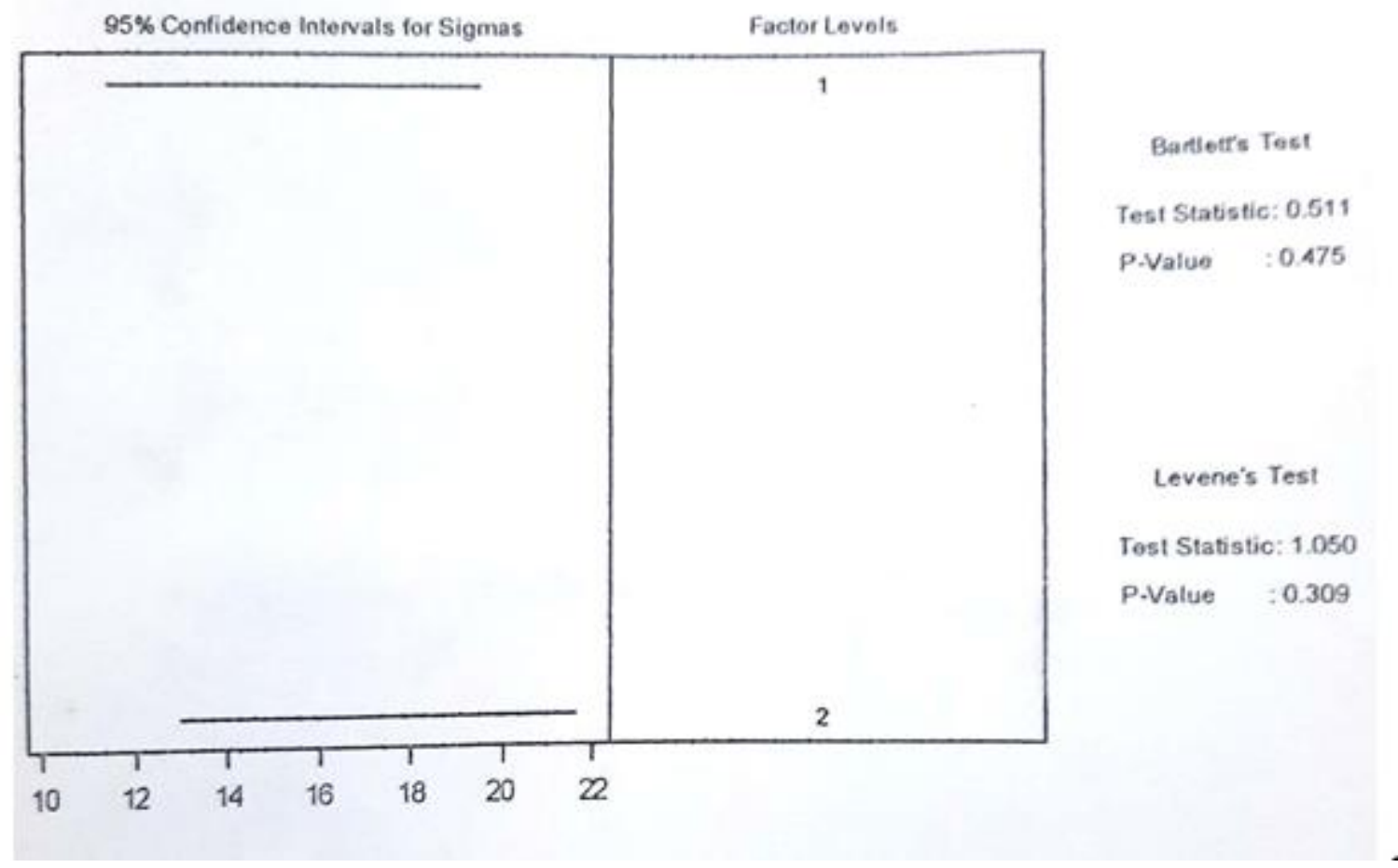

\section{Gambar 3. Uji Homogenitas Kelas Sampel}

Dari hasil uji homogenitas terlihat bahwa selang kepercayaan masing-masing kelas sampel beririsan atau harga P-value yaitu 0,475 lebih besar dari taraf nyata yang telah = ditetapkan yaitu $\alpha=0,05$. Jadi dapat disimpulkan bahwa kelas sampel homogen.

Karena kedua kelas sampel berdistribusi normal dan homogen, selanjutnya dilakukan uji hipótesis menggunakan uji-t. Dalam hal ini $\mathrm{H}_{0}: \mu_{1}=\mu_{2}$ dan $\mathrm{H}_{1}: \mu_{1}>\mu_{2}$. Kriteria pengujiannya adalah terima $\mathrm{H}_{0}$ jika $\mathrm{t}_{\text {hitung }}<\mathrm{t}_{\text {tabel }}$ dan tolak $\mathrm{H}_{0}$ untuk harga-harga lainnya. Dari 
hasil perhitungan diperoleh $t_{\text {hitung }}=2,33$, sedangkan pada $==\mathrm{a}=0,05 \mathrm{dan} \mathrm{dk}=77$, diperoleh harga $t_{\text {tabel }}=1,67$. Berdasarkan perhitungan $>$ dari data penelitian ini diperoleh $t_{\text {hitung }}>t_{\text {tabel }}$, hal ini berarti $\mathrm{H}_{0}$ ditolak dan $\mathrm{H}_{1}$ diterima. Jadi dapat disimpulkan bahwa hasil belajar matematika siswa yang belajar menggunakan metode resitasi lebih baik daripada hasil belajar menggunakan metode resitasi.

\section{Pembahasan}

Dari hasil analisis data tes akhir diketahui bahwa hasil belajar matematika siswa kelas eksperimen lebih baik daripada kelas kontrol. Ini menunjukan bahwa penggunaan metode resitasi dalam permbelajaran matematika memiliki dampak positif terhadap hasil belajar matematika siswa. Hal ini terlihat dari nilai tertinggi kelas eksperimen yaitu 100 dan nilai terendahnya 38. sedangkan untuk kelas kontrol nilai tertingginya 85 dan terendah 20 . Tingginya hasil belajar matematika kelas eksperimen daripada kelas kontrol disebabkan karena pada saat pembelajaran dengan menggunakan metode resitasi siswa lebih banvak bekerja dan berlatih melalui tugas-tugas yang juga memberikan kesempatan lebih luas pada siswa untuk memahami materi matematika dan terlatih dalam mengerjakan soal-soal matematika Kondisi ini juga didukung oleh usaha guru yang selalu memeriksa, menilai, dan mengembalikan hasil kerja siswa yang dapat memacu semangat siswa untuk memperoleh yang lebih baik lagi. karena mereka mengetahui kesalahan mereka. Berbeda dengan kelas kontrol. siswa juga diberi latihan, kemudian dinilai dan dan dikembalikan lagi kepada siswa namun setelah siswa melihat hasil kerja mereka tidak berusaha untuk memperbaiki kesalahan mereka dalam mengerjakan latihan. Siswa malas untuk bertanya kembali, pada guru tatau berdiskusi dengan temannya yang lebih mengerti. Sehingga kesalahan mereka dalam memahami konsep matematika terulang lagi untuk latihan-latihan berikutnya. Hal ini sesuai dengan yang dijelaskan oleh Mudhofir (2016: 120) bahwa metode pemberian tugas dan resitasi mempunyai beberapa kelebihan, antara lain: memotivasi peserta didik untuk melaksanakan pembelajaran secara individual maupun kelompok, dapat mengembangkan kemandirian peserta didik di luar pengawasan guru, dapat membina Implementasi Metode Resitasi tanggung jawab dan disiplin peserta didik, dan dapat mengembangkan kreativitas peserta didik. Hasi penelitian ini sejalan dengan peneliti lain yang dilakukan oleh Dedy Yusuf Aditya pada tahun 2016 yang juga menggunakan metode resitasi dalam penilitiannya yang berjudul "Pengaruh Penerapan Metode Resitasi Terhadap Hasil Belajar Matematika Siswa Kelas VII SMP AT-TAQWA" menyimpulkan bahwa hasil belajar matematika siswa yang diajar dengan menggunakan metode pembelajaran resitasi lebih tinggi dari hasil belajar matematika siswa yang diajar dengan metode klasikal.1 Dengan kata lain, dapat disimpulkan terdapat pengaruh dari penerapan pembelajaran metode resitasi terhadap hasil belajar matematika siswa. Dari uraian diatas serta dukungan dari hasil penelitian terdahulu dapat disimpulkan bahwa pembelajaran dengan menggunakan metode resitasi jauh lebih baik dari pada metode konvensional.

\section{KESIMPULAN}

Tugas-tugas siswa yang dirancang guru dalam bentuk lembar resitasi dan dikerjakan sebelum pembelajaran dapat meningkatkan respon belajar siswa pada saat pembelajaran berlangsung. Selain itu dapat memberikan kesempatan luas bagi siswa untuk mengembangkan pengetahuannya, sehingga hasil belajar siswa lebih baik. Pemberian tugas awal yang dirancang dalam bentuk lembar resitasi yang diteruskan dengan pemberian latihan kepada siswa secara kontinu setiap selesai materi dibicarakan dapat menambah pemahaman yang lebih baik bagi siswa, ini terbukti dari rata-rata nilai latihan siswa di kelas eksperimen lebih tinggi dari pada nilai rata-rata siswa di kelas kontrol. Dengan penggunaan metode resitasi ini diharapkan peserta didik mempunyai kesempatan untuk memperkaya dan memperluas pengetahuan serta pengalamannya. 


\section{DAFTAR PUSTAKA}

Aditya, Dedy Yusuf. (2014). Pengaruh Penerapan Metode Pembelajaran Resitasi Terhadap Hasil Belajar Matematika Siswa. Jurnal SAP Universitas Indraprasta PGRI: Jakarta

Bahri Djamarah, Syaiful. (2008). Psikologi Belajar. (Jakarta: PT. Rineka Cipta)

Bakar, Usman. (2005). "Evaluasi Hasil Pembelajaran Berbasis Kompetensi Dimensi Afektif di bidang MIPA. Padang: UNP.

Hudojo, Herman, dkk. (2001). Strategi Belajar-Mengajar Matematika kontemporer. Malang: Jurusan Matematika FMIPA Universitas Negeri Malang.

Irma, Miskah. (2004). "Perbedaan Hasil Belajar Matematika Pembelajarannya menggunakan Metode Resitsi dengn pembelajaran Biasa di Kelas VIII SMUN 7 Padang”. (skripsi). Padang: UNP.

Kusrini, dkk. (2003). Matematika. Jakarta: Depdiknas Direktorat Jenderal Pendidikan Dasar dan Menengah.

Lazwardi, Lisa. (2003). Pengaruh Metode Resitasi Pada Pembelajaran Fisika Terhadap Hasil Belajar Fisika Siswa Kelas VIII SLTPN 16 Padang (skripsi). Universitas Negeri Padang. Padang.

Mudhofir, Ali. (2016). Desain Pembelajaran Inovatif. Rajawali Press. Jakarta

Sudjana. (1992). Metode Statistika. Tarsito.Bandung

Sundayana, Rostina. (2016). Media dan Alat Peraga dalam Pembelajaran Matematika. Alfabeta. Bandung

Suharsimi. (1997). Prosedur Penelitian Suatu pendekatan. Rineka cipta. Jakarta.

Suryabrata, Sumadi. (2002). Metodologi Penelitian. PT Raja Grafino Persada. Jakarta

Syafriandi. (2001). Analisis Statistika Inferensial dengan Menggunakan Minitab: Universitas Negeri Padang. Padang 